\title{
The effectiveness of the project-based learning (PrjBL) approach in undergraduate accounting education
}

\author{
Amalia Carrasco Gallego (gallego@us.es) \\ José Antonio Donoso Anes (jadonoso@us.es) \\ Teresa Duarte Atoche (tduarte@us.es) \\ Julián Hernández Borreguero (julianhdez@us.es) \\ Rosario López Gavira (lgrosa@us.es) \\ Universidad de Sevilla (España) \\ http://dx.doi.org/10.12795/EDUCADE.2018.109.05
}

RESUMEN: Desde la década de los 90 organismos profesionales de contabilidad como la American Accounting Association (AAA) o la International Financial Accounting Committe (IFAC) vienen demandando la necesidad de usar metodologías de participación activa en la formación universitaria de la contabilidad que faciliten el desarrollo de competencias y habilidades profesionales.

El objetivo del trabajo es analizar la eficacia de ABPrj en la formación universitaria en asignaturas de Contabilidad Superior. El constructo de eficacia se ha formado por la utilidad para el aprendizaje de la materia y el desarrollo de competencias demandadas por la profesión y la mejora del rendimiento.

El instrumento de medida es el cuestionario CEMPA (Cuestionario de efectividad del uso de metodologías de participación activa), que mide la percepción de eficacia de las metodologías de participación activa en el desarrollo de competencias técnicas y no técnicas (competencias) y análisis de rendimientos.

Los resultados obtenidos confirman que los alumnos implicados en ABPrj perciben su utilidad para el aprendizaje y para el desarrollo de competencias demandadas para la profesión contable. Obtienen mejores rendimientos. Adicionalmente, se observa que la eficacia del ABPrj está relacionada con el tipo de materia; es más eficaz en asignaturas con un perfil creativo y abierto en su interpretación que aquellas más normativas.

El estudio presenta limitaciones de carácter interno como externo, basadas en poco reconocimiento del tiempo invertido y la exigencia de prueba final igual para todos los alumnos.

PALABRAS CLAVE: Aprendizaje basado en proyectos, método de aprendizaje, método activo, aprendizaje activo.

ABSTRACT: Since the 1990s, professional accounting bodies such as the American Accounting Association (AAA) and the International Financial Accounting Committee (IFAC) have insisted on the necessary use of active participation techniques in undergraduate accounting education to facilitate the development of professional skills and abilities. 
The purpose of this paper is to analyse the effectiveness of project-based learning (PrjBL) in university education in Advanced Accounting courses. The construct of effectiveness was created for its usefulness to learn the subject, develop skills desired in the profession, and improve achievement.

The CEMPA questionnaire (Questionnaire Measuring the Effectiveness of Active Participation Techniques, Cuestionario de efectividad del uso de metodologías de Participación Activa) is a tool measuring the perceived effectiveness of active participation techniques in the development of technical and non-technical skills and analysing achievement.

The results confirm that students involved in PrjBL perceive it as useful for learning and developing skills desired in the accounting profession. Students perform better. Additionally, it appears that PrjBL effectiveness is related to the type of subject; it is more effective in courses with a creative profile open to interpretation than it is in more prescriptive courses.

This study has internal and external limitations based on the limited recognition of the time spent and the requirement of a final test identical for all students.

KEYWORDS: Project-based learning, learning method, active method, active learning.

Artículo. Recibido: 20-04-18 - Versión revisada: 12-09-18; 16-11-18, Aceptado: 28-11-18

Licencia Creative Commons BY NC ND · $2018 \cdot$ Asociación Española de Contabilidad y Administración de Empresas - AECA

\section{INTRODUCTION}

In recent years, changes have been encouraged in the methodological paradigm of higher education in the educational and professional fields (De Miguel Diaz, 2005). Education has changed from a method centred on the teacher's task to a learnercentred method based on participatory learning in which students assume responsibility for their academic training. Organizations such as the American Accounting Association (AAA) and the International Financial Accounting Committee (IFAC) have shown that there was a lack of development of certain skills and abilities required for problem solving, critical thinking, and communication in accounting education (Springer \& Borthick, 2004). To remedy this deficit, they offer the use of methods that actively involve students in the learning process. The introduction of participatory methodologies in accounting education has had mixed results, and they have not been proven effective. According to Hwang, Lui, and Tong (2005), the use of these methodologies improves students' abilities to apply the knowledge learnt in the classroom, and this improvement is particularly significant when students face more complex accounting problems.

Project-based learning (PrjBL) emerged in the 1990s in the experimental workshops of the Expeditionary Learning Outward Bound (Rugen \& Hart, 1994) and in various academic circles related to pedagogy (Blumenfeld et al., 1991). It is defined as a set of complex tasks involving students in designing, problem solving, decision making, and research activity, giving them the opportunity to learn independently for extended periods of time, and resulting in final presentations (Jones, Rasmussen, \& Moffitt, 1997; Thomas, Mergendoller, \& Michaelson, 1999). No work verifying the implementation of PrjBL has been found in the literature review on accounting teaching (Apostolou, Dorminey, Hassell, \& Watson, 2013; Apostolou, Hassell, Rebele, \& Watson, 2010; 
Apostolou, Watson, Hassell, \& Webber, 2001; Elam, 1996; Rebele et al., 1988a, 1988b; Rebele, Stout, \& Hassell, 1991; Watson, Apostolou, Hassell, \& Webber, 2003, 2007).

The purpose of this paper is to analyse the effectiveness of PriBL in university education in Advanced Financial Accounting (AFC), and Financial Accounting Analysis (AA) courses. The construct of effectiveness was formed for its usefulness for learning the subject and developing skills desired in the profession, measured by students' perception through the Questionnaire Measuring the Effectiveness of Active Participation Techniques (Cuestionario de efectividad del uso de metodologías de Participación Activa (CEMPA)) and improved performance. The results confirm that students involved in PrjBL perceive its usefulness for learning and developing the skills desired in the accounting profession.

This paper is divided into a review of the main contributions in the use of active participation methodologies, hypotheses, a presentation of the PriBL approach, sample, measurement, and variables; it concludes with research results, discussion, conclusions, and limitations.

\section{ACTIVE PARTICIPATION TECHNIQUES AND ACCOUNTING EDUCATION}

Methodologies of active or participatory teaching originate from Piaget (1970) and Vygotsky's (1978) constructivism theory. They rely on an understanding of how the human brain works, how it stores and retrieves information, how it learns, and how learning increases and extends prior learning (Galeana de la $O, 2006$ ). Constructivism focuses on learning as the result of mental constructs that are learnt by building new ideas or concepts based on current and previous knowledge (Karlin \& Viani, 2001). According to this theory, the key component of a project must include a way for students to transform and build knowledge (Bereiter \& Scardamalia, 1999).

In the 1990s, the American Accounting Association (AAA) and the International Financial Accounting Committee (IFAC) showed that there was a lack in developing non-technical skills and abilities (problem solving, critical thinking, and communication and interpersonal skills, (Springer \& Borthick, 2004) in accounting education. In response to this deficit, they encouraged the use of methods actively involving students in the learning process to achieve more flexible, lasting, and easily applicable knowledge (Boaler, 1998). In this spirit, Knechel (1992), Bonner (1999), and Hwang et al. (2005) suggested that the use of these methodologies improves students' skills to apply the knowledge they have learnt in the classroom, and this improvement is particularly significant when students face more complex accounting problems.

Empirical studies on the effectiveness of using active methodologies in accounting appear to have mixed results. Most studies highlight the positive effects of their use, such as Deci and Ryan (1985), who defend the usefulness of these methodologies based on motivational aspects, showing that, in terms of what are known as intrinsic and extrinsic motivations, students often find teamwork more interesting than lectures or textbook reading. Benware and Deci (1984) show that students who attain this intrinsic (also called active) stimulation achieve a greater level of motivation than those who only resort to extrinsic stimulation.

Other studies recommend improving aspects that optimize the use of these methodologies. Thus, May, Windal, and Sylvestre (1995) acknowledge that, although it 
is necessary to put more emphasis on skills such as oral and written communication, intellectual, or problem-solving skills, most respondents are not in favour of group learning or the use of case studies. They also observe that there are several shortcomings that need to be improved for the success of these active methodologies, such as the lack of suitable materials, classroom design, students' resistance to bearing more responsibility for their own learning, and teacher training.

Indeed, the successful implementation of these active methodologies implies taking the key role of teachers fully into account; they must be aware that they cease to play the exclusive role of transmitting knowledge and instead become a coach or coordinator of the student learning (Springer \& Borthick, 2004), which is why training them on this changing role is fundamentally important. Moreover, their work implies the need for planning, monitoring activities, mastering group dynamics technique, and having a sense of equity in assessment among teams.

In accounting teaching, different types of active methodologies are used, such as the case study method, which is a problem-based, activity-based, and simulation-based approach to learning. From a theoretical framework, project-based learning (PrjBL) has elements in common with case study, activity-based learning, and problem-based learning (Cullen, Richardson, \& O'Brien, 2004; Goodfrey, 1995; Hand, 2004a, 2004b); they are linked (Penzo, 2009) in that they use previous information content, carry out actions connected to the real world and provide teachers with feedback on the effectiveness of their implementation, with students being responsible for planning, implementing, and evaluating projects (Blank, 1997; Dickinson et al., 1998; Galeana de la O, 2006; Harwell, 1997). The differences lay in the time frame of their implementation and in their emphasis. PrjBL takes a long period of time (from one quarter to a full course) and emphasizes the design and development of a plan for teamwork.

PrjBL implies studying the subject using a company's actual information. To achieve pedagogical usefulness, (Durtschi, 2003; Wassermann, 1999), it must include a concrete situation taken from reality (i.e., not simulated), be a problematic or complex situation that leads to a diagnosis or a decision, and be a situation that can provide information and training on a particular knowledge area.

The work sequence must be well defined and fall within an appropriate context. The necessary information must be identified by the student to solve the case; therefore, all the information must not be provided at the beginning of the activity (Durtschi, 2003; Norman \& Schmidt, 1992).

The view expressed by various authors is that this methodology develops the ability to search for and implement information, solve problems, and work in a team (Candy, Crebert, \& O'Leary, 1994); it facilitates and accelerates the learning of new concepts and the application of those already established (Greenstein \& Hall, 1996). It helps students better understand ideas and concepts that were used during the course of the experience (Cullen et al., 2004; Reynolds, 1990); it develops transferable skills, such as teamwork, project planning, drafting technical reports, making presentations, and searching for documents (Martinez, Ruiz, Perez, \& Gonzalez, 2007), as well as independence and responsibility when facing an actual complex situation (Godejord, 2007), in addition to other skills, such as communication, decision making, and the ability to relate theory to practice. It allows for comparing knowledge learnt in the 
classroom with its application to real situations and developing the skills required for professional development (Barron et al., 1998).

In our case, PriBL was used to learn Advanced Financial Accounting (AFA) and Accounting Analysis (AA). Starting from the actual information generated by companies (financial statements), the purpose was for students to learn their financial statements' design and content in accordance with the Spanish Chart of Accounts forms, recording and evaluating the rules. With these data and other complementary information, students were to assess and analyse the company's economic and financial situation over a period of time. AFA and AA are two disciplines with very different objectives and contents that entail the development of distinct technical and non-technical skills: AFA is very prescriptive, aligned, structured, and organized, whereas AA is open, interpretative, and creative despite its structured method.

\section{HYPOTHESES DEVELOPMENT AND METHODOLOGY}

The purpose of this paper is to analyse the effectiveness of the PriBL approach in Advanced Accounting (AFA and AA) courses. The construct of effectiveness was created for its usefulness for learning and developing skills desired in the profession. Usefulness is measured through students' perception of it and the performance variable obtained by each student. The development of skills desired in the profession is assessed through the perception that students have of them.

As noted, students involved in the PriBL approach face a scenario emerging from the actual context: they use different sources of available information, obtain real information, verify the reliability of the data, apply the current regulations, and have limited time available for carrying out activities. With this process, students acquire the knowledge to study financial statements, direct analysis in different environments, and develop tasks to be performed in any process of rigorous financial analysis.

The Bedford Report (AAA, 1986) notes that the training of future professionals in accounting must fully account for actual situations and continuous changes in society and the environment, as well as the ability to adapt to them. As indicated by Hwang et al. (2005), using active participation methodologies may improve students' abilities to apply the knowledge they have learnt in the classroom or, as Marriot and Marriot (2003) note, allow students to better understand the accounting profession. Thus, the first hypothesis proposed is the following:

\section{H1: Students involved in PrjBL see its usefulness for learning}

Considering what Reyes (2005) and Hwang et al. (2005) note, students who learn through participatory methodologies better retain the acquired knowledge, better apply it to specific cases, and are more critical; thus, it is assumed that the scores obtained by students who develop their learning through PriBL would be higher than those obtained by other students learning through a non-participatory methodology. Thus, the second hypothesis is as follows:

H2: Students involved in PriBL have a better level of performance than those who are not.

Friedlan (1995) states that the use of small cases in a 'non-traditional' course has a significant effect on students' perceptions of the skills required for academic and 
professional success, and they are consistent with the skills that professional accountants identify as necessary for any graduate. The main skills required for professional accountants are the following: decision making, teamwork, and oral and written communication (e.g., AECC, 1990; White Paper, 1989). Thus, the third hypothesis is derived:

H3: Students involved in PrjBL perceive they develop skills desired in the profession.

\section{Sample, measuring instrument, and variables}

To test the hypotheses, a database of students who participated in PrjBL was developed during 2 consecutive academic years (AY1 and AY2). The database included their perceptions of usefulness, skills, and their scores.

To measure students' perceptions, the CEMPA questionnaire was produced and validated using confirmatory factor analysis by Carrasco, Donoso, Duarte, Hernández, and López (2011). The first part of the questionnaire consists of closed-ended questions rated using a 5-point Likert scale to measure the perceived effectiveness of active participation techniques in the development of technical and non-technical skills. In turn, non-technical skills are divided into instrumental, systemic, and interpersonal skills (Zabalza, 2003). Instrumental skills provide students with learning and training tools; systemic skills relate to seeing the big picture and the ability to properly manage the entire intervention; and interpersonal skills are those associated with the development of abilities to maintain good social relationships with others. The second part of the questionnaire is descriptive, consisting of open-ended questions.

The first part of the questionnaire is based on 25 items. The first 5 are related to the perception of the usefulness of the methodology for learning the subject and are linked to Hypothesis $1(\mathrm{H1})$. These items are the following: helps verify the knowledge learnt in the classroom with its application to real situations; helps bridge the gap between theory and practice; facilitates the process of learning the subject; involves the participants in their own learning; and creates an attitude of active participation.

$\mathrm{H} 3$ (skills desired in the profession) is linked to the remaining items in the questionnaire: time management, problem-solving, decision-making, planning, delegating, selfmotivation, teamwork, conflict management, negotiation, leadership, and intellectual stimulation, among others.

Performance $(\mathrm{H} 2)$ is measured in terms of project scores', the exam scores, and the final scores for each subject².

\footnotetext{
1 The project score ranges between 0 and 3. Each student-member of a working group was individually assessed even though he/she was conditioned by the group's achievement measured through mandatory tutorial sessions.

2 The course score for students participating in PrjBL was the sum of the exam score (if it was equal to or greater than 4) and the project score. For students who did not participate in PrjBL, the final score was the score received on the exam.
} 
In total, data from 896 individuals, 557 in AFA and 339 in AA (Tables IX and X), were collected. From this database, a descriptive analysis of the questionnaire items and an analysis of student performance were performed through a linear regression between the exam score and the project score.

\section{RESEARCH RESULTS}

\section{Descriptive analysis of the survey items}

The Cronbach's alpha associated with the questionnaires for both subjects and for AY 1 and AY2 ranged between 0.860 and 0.906 , near 1 , indicating that the instrument built on the 25 items is reliable and produces stable measurements.

The mean scores of the perception of usefulness (Table I) of both courses were 3.80 in AFA and 4.38 in AA. In AA, the values were all above 4, highlighting the following items: helps verify the knowledge learnt in the classroom with its application to real situations (4.48), involves the participants in their own learning (4.47), and facilitates the learning of AA (4.43). In AFA, the main perceptions are the following: creates an attitude of active participation (4.01) and involves participants in their own learning (4.00).

Table I. Usefulness and technical skills of PrjBL (1-5 scale)

\begin{tabular}{|c|c|c|}
\hline & AFA & AA \\
\hline Mean & 3.80 & $4.38\left(^{*}\right)$ \\
\hline $\begin{array}{l}\text { 1- Helps verify the knowledge learnt in the classroom with its application } \\
\text { to real situations }\end{array}$ & 3.86 & $4.48(*)$ \\
\hline 2- Helps bridge the gap between theory and practice & 3.52 & 4.31 \\
\hline 3- Facilitates the learning of AFA and/or AA & 3.61 & $4.43(*)$ \\
\hline 4- Involves participants in their own learning & $4.00\left(^{*}\right)$ & $4.47(*)$ \\
\hline 5- Creates an attitude of active participation & $4.01\left(^{*}\right)$ & 4.24 \\
\hline
\end{tabular}

The results in Table II show that students perceive that they develop non-technical skills in both AA and AFA, in instrumental (3.92 and 3.73, respectively), systemic (3.74 and 3.53, respectively), and interpersonal (3.89 and 3.66, respectively) skills. Teamwork (4.43; $4.47)$, computer use $(4.15 ; 4.14)$, and interpersonal communication $(4.23 ; 3.91)$ stand out. Additionally, students assigned a high score to conflict management in AFA (4.00) and oral (4.11) and written (4.13) communication in AA.

In the second part of the questionnaire (descriptive) related to the time dedicated to PrjBL, the answers were highly varied. Time varied from 12 to 70 hours in AFA and from 15 to 120 hours in AA. Tutorials were highly scored in both subjects, with a mean of 4.31 in AFA and 4.73 in AA. A total of $90 \%$ of the respondents in AFA and $100 \%$ of the respondents in AA regarded the tutorials as sufficient and essential to carry out the work.

Additionally, the students were requested to highlight the positive and negative aspects of the project, without a predefined list. The responses were consistent with the best-scored skills in Table I (teamwork, application to real situations, helps verify knowledge, improves understanding of the subjects). Regarding negative aspects, the 
responses highlighted the large amount of time invested and insufficient weighting in the final score of the course.

Table II. Non-technical skills in PrjBL (1-5 scale)

\begin{tabular}{l|cc}
\hline & AFA & AA \\
\hline Instrumental skills & $3.73\left(^{*}\right)$ & $3.92\left(^{*}\right)$ \\
6- Time management & 3.21 & 3.56 \\
7- Problem-solving & 3.72 & 3.92 \\
8- Decision-making & 3.77 & 3.85 \\
9- Planning & 3.66 & 3.78 \\
10- Computer use & $4.14\left(^{*}\right)$ & $4.15\left(^{*}\right)$ \\
11- Database management & 3.84 & 3.84 \\
12. Oral Communication & 3.88 & $4.11\left(^{*}\right)$ \\
13. Written communication & 3.64 & $4.13\left({ }^{*}\right)$ \\
Systemic skills & $3.53\left(^{*}\right)$ & $3.74\left(^{*}\right)$ \\
14- Creativity & 3.5 & 3.59 \\
15- Management by objectives & 3.52 & 3.66 \\
16- Project Management & 3.43 & 3.68 \\
17- Intellectual stimulation & 3.8 & 3.93 \\
18- Delegating & 3.38 & 3.82 \\
Interpersonal skills & $3.66\left(^{*}\right)$ & $3.89\left(^{*}\right)$ \\
19- Self-motivation & 3.41 & 3.92 \\
20- Awareness of ethics & 3.04 & 3.45 \\
21- Interpersonal communication & 3.91 & $4.23\left(^{*}\right)$ \\
22- Teamwork & $4.47\left(^{*}\right)$ & $4.43\left(^{*}\right)$ \\
23- Conflict management & $4\left(^{*}\right)$ & 3.98 \\
24- Negotiating & 3.58 & 3.67 \\
25- Leadership & 3.23 & 3.57 \\
\hline
\end{tabular}

The students conducted a comprehensive final evaluation of the methodology. AA scored 4.40 and AFA 3.92. In accordance with these evaluations, $71.5 \%$ of the students involved in AFA, but only $40 \%$ in AA considered that it should not be mandatory. Most participants (58\% in AFA and $79 \%$ in AA) commented that the methodology was optimal for learning, with $70 \%$ in AFA and $84 \%$ in AA stating that they would repeat the experience.

\section{Score analysis}

To conduct the analysis of academic achievement, the following variable was controlled: prior ability of the students who participated in PriBL and those who did not. To that end, an analysis of the students' mean scores in accounting during previous academic years was performed. The results showed no significant differences in previous scores, and thus, the ability of students involved in both samples is controlled, which means that prior ability is not an influencing factor affecting the results obtained $^{3}$.

\footnotetext{
3 See means analysis in Appendix 1.
} 


\section{Score analysis in AFA}

A descriptive comparative analysis between the students who were involved in PrjBL (with projects) and those who were not (without any project) was conducted as though they were 2 independent samples, considering the exam score as an indicator of academic success ${ }^{4}$. Table III shows the descriptive statistics relating to the 2 groups for $A Y 1$ and $A Y 2$, reporting the difference between the average score of students who have undertaken a project (4.57 and 5.19, respectively) and those who have not (3.72 and 4.28 , respectively).

Table III. Descriptive statistics of the two groups for AY1 and AY2.

\begin{tabular}{|c|c|c|c|c|c|}
\hline & Students... & Sample Size & Mean & $\begin{array}{l}\text { Standard } \\
\text { deviation }\end{array}$ & $\begin{array}{c}\text { Standard error } \\
\text { of mean }\end{array}$ \\
\hline \multicolumn{6}{|c|}{ AY1 } \\
\hline \multirow[t]{2}{*}{ Exam score } & $\begin{array}{l}\text { Without } \\
\text { project }\end{array}$ & 161 & $3.73(*)$ & 2.11 & 0.167 \\
\hline & With project & 66 & $4.57(*)$ & 2.40 & 0.298 \\
\hline \multicolumn{6}{|c|}{ AY2 } \\
\hline \multirow[t]{2}{*}{ Exam score } & $\begin{array}{l}\text { Without } \\
\text { project }\end{array}$ & 275 & 4.30 & 2.04 & 0.123 \\
\hline & With project & 55 & $5.20\left(^{*}\right)$ & 1.87 & 0.252 \\
\hline
\end{tabular}

To check the equality of variances between both groups and courses, the Levene's test (Table IVa) is performed; showing that it is the same $(p=0.310$ and $p=0.526)$, this leads to calculating the $t$-statistic (Table IV b). The value of the t-statistic (-2.621 and 3.038,) and the associated $\mathrm{p}$-value (0.009 and 0.003 ) result in the finding that there are significant differences between both scores ${ }^{5}$.

Table IV. Levene's test and Student's t-test

\begin{tabular}{l|cc|ccccc}
\hline & \multicolumn{2}{|c|}{$\begin{array}{c}\text { a) Levene's fest for } \\
\text { equality of variances }\end{array}$} & \multicolumn{5}{c}{ b) t-test for equality of means } \\
& $\mathrm{F}$ & Significance & $\dagger$ & gl & $\begin{array}{c}\text { Significance (2 } \\
\text { tailed) }\end{array}$ & $\begin{array}{c}\text { Mean } \\
\text { difference }\end{array}$ & $\begin{array}{c}\text { Standard } \\
\text { error of the } \\
\text { difference }\end{array}$ \\
AY1 & 1.036 & 0.310 & -2.621 & 224 & 0.009 & -0.84544 & 0.32260 \\
AY2 & 0.403 & 0.526 & 3.038 & 328 & 0.003 & 0.90207 & 0.29695 \\
\hline
\end{tabular}

Comparing the percentiles of both distributions (Table $\mathrm{Va}$ ) shows that the median of students in the 'without project' group for AY1 is 3.80, which means that half of the students have a score below 3.8, whereas half of the students in the 'with project' group have a score higher than 4.5 and pass the course with the project score. For AY2, half of the students in the 'without project' group obtain a score below 4.1; thus, they

\footnotetext{
${ }^{4}$ Even though the course score consisted of the exam score and the project score, we believe that successful learning is more appropriately demonstrated by the exam score.

5 The null hypothesis in this contrast is the equality of means, which is rejected under the p-value.
} 
Carrasco, Donoso, Duarte, Hernández \& López

The effectiveness of the project-based learning approach in undergraduate acc. education

do not pass the course. However, $75 \%$ of the students in the 'with project' group pass the course, even though their exam result is equal to 4.

Table V: Percentiles

\begin{tabular}{l|ccccccc}
\hline a) $\mathbf{A Y 1}$ & $\mathbf{5}$ & $\mathbf{1 0}$ & $\mathbf{2 5}$ & $\mathbf{5 0}$ & $\mathbf{7 5}$ & $\mathbf{9 0}$ & $\mathbf{9 5}$ \\
\hline Without project & 0.0000 & 0.5000 & 2.3500 & 3.8000 & 5.0000 & 6.1400 & 7.5400 \\
With project & 1.0000 & 1.2300 & 2.8000 & 4.5000 & 6.1250 & 8.5000 & 9.1400 \\
\hline b) AY2 & $\mathbf{5}$ & $\mathbf{1 0}$ & $\mathbf{2 5}$ & $\mathbf{5 0}$ & $\mathbf{7 5}$ & $\mathbf{9 0}$ & $\mathbf{9 5}$ \\
\hline Without project & 0.9800 & 1.6600 & 2.9000 & 4.1000 & 5.5000 & 7.1400 & 8.0000 \\
With project & 2.0600 & 2.8000 & 4.0000 & 5.3500 & 6.5000 & 7.8200 & 8.5000 \\
\hline
\end{tabular}

When deepening the analysis of Table $V(a, b)$, it can be observed that students in the 'with project' group obtain higher scores than students in the 'without project' group in all percentiles. At the extremes and for AY1, it can be observed that $10 \%$ of the students in the 'with project' group obtain a score above 8.5 and more than $5 \%$ obtain the best scores; for AY2, the scores in the last 2 percentiles decrease but are always above those of the students in the 'without project' group. Scores near 0 are not observed in the distribution of students in the 'with project' group.

When using the sample of students in the 'with project' group, the linear relationship between the project score (explanatory variable) and the exam score (explained variable) is examined. The result of the Ordinary Least Squares (OLS) estimator is shown in Table VI.

Table VI. Linear relationship between the project score and the exam score

\begin{tabular}{|c|c|c|c|c|c|}
\hline & & \multicolumn{2}{|c|}{$\begin{array}{l}\text { non-standardized } \\
\text { coefficients }\end{array}$} & \multirow[t]{2}{*}{$T$} & \multirow[t]{2}{*}{ Sig. } \\
\hline & & $B$ & $\begin{array}{l}\text { Standard } \\
\text { error }\end{array}$ & & \\
\hline AY1 & $\begin{array}{l}\text { (Constant) } \\
\text { Project score }\end{array}$ & $\begin{array}{c}0.606 \\
1.976\left(^{*}\right)\end{array}$ & $\begin{array}{l}1.165 \\
0.564\end{array}$ & $\begin{array}{l}0.520 \\
3.503\end{array}$ & $\begin{array}{c}0.605 \\
0.001\left(^{*}\right)\end{array}$ \\
\hline AY2 & $\begin{array}{l}\text { (Constant) } \\
\text { Project score }\end{array}$ & $\begin{array}{c}3.930 \\
0.661\left(^{*}\right)\end{array}$ & $\begin{array}{l}1.343 \\
0.691\end{array}$ & $\begin{array}{l}2.926 \\
0.956\end{array}$ & $\begin{array}{c}0.005 \\
0.343\left({ }^{*}\right)\end{array}$ \\
\hline
\end{tabular}

The estimated slope value (1.976) indicates that an increase of 1 point in the project score may result in an increase of almost 2 points in the exam score. There is a positive linear correlation of 0.404 significant at $1 \%$ between the project score and the exam score for $A Y 1$, although $R^{2}$ is weak (0.163), which implies that other variables not included in the study also explain the exam score. For AY2, there is also a positive relationship between the project score and the exam score, but it is not significant.

\section{Score analysis in AA}

In the descriptive comparative analysis between AA students in the 'with project' group and students in the 'without project' group, the exam score is considered an indicator of academic success, as in AFA. These descriptive statistics are shown in Table VII. 
Carrasco, Donoso, Duarte, Hernández \& López The effectiveness of the project-based learning approach in undergraduate acc. education

Table VII. Descriptive statistics

\begin{tabular}{l|lcccc}
\hline & & N & Mean & $\begin{array}{c}\text { Standard } \\
\text { Deviation }\end{array}$ & $\begin{array}{c}\text { Standard } \\
\text { error }\end{array}$ \\
\hline \multirow{3}{*}{ AY1 } & Without project & 103 & 3.6733 & 1.49448 & 0.19524 \\
& With project & 61 & 5.6131 & 1.55469 & 0.19906 \\
& Total & 164 & 4.3968 & 1.51687 & 0.19666 \\
AY2 & Without project & 107 & 3.8893 & 1.89974 & 0.18365 \\
& With project & 68 & 5.2434 & 1.84470 & 0.22370 \\
& Total & 175 & 4.4154 & 1.87835 & 0.19921 \\
\hline
\end{tabular}

The mean score of students in the 'with project' group is significantly higher than that of students in the 'without project' group. Both groups ('without project' versus 'with project') show a difference of 2.2 points in favour of the latter.

The findings show that the standard deviations of each group have similarities, such that the null hypothesis of equality of variances in the groups may be maintained. In the Levene's test (Table VIII), the results (for AY1, $p=0.899$; for AY2, $p=0.268$ ) show that variability in the groups is the same.

Table VIII. Test of variance homogeneity.

\begin{tabular}{l|rrrrr}
\hline & \multicolumn{5}{|c}{ Exam score } \\
\hline & Levene's test & gl1 & gl2 & Sig. \\
AY1 & 0.197 & & 1 & 164 & $\mathbf{0 . 8 9 9}$ \\
AY2 & 1.323 & 1 & 275 & $\mathbf{0 . 2 6 8}$ \\
\hline
\end{tabular}

The analysis of variance (ANOVA) test associated with this contrast (Table IX) of variance homogeneity leads us to reject the null hypothesis of equality of means between the groups for both academic years, i.e., the scores show significant differences between the 'with project' and 'without project' groups $(p=0.000)$.

Table IX. ANOVA analysis

\begin{tabular}{l|lccccc}
\hline & \multicolumn{7}{|c}{ Exam grade } \\
\hline \multirow{3}{*}{ AY1 } & & Sum of squares & Gl & Mean square & F & Sig. \\
& Inter-groups & 212.940 & 1 & 70.980 & 30.179 & $\mathbf{0 . 0 0 0}$ \\
& Intra-groups & 644.442 & 164 & 2.352 & & \\
& Inter-groups & 148.159 & 1 & 74.080 & 19.363 & $\mathbf{0 . 0 0 0}$ \\
& Intra-groups & 876.120 & 175 & 3.826 & & \\
\hline
\end{tabular}

A pairwise comparison is performed in the context of post-hoc analysis using Tukey's HSD (equal variances) Test, which best controls the error rate in different situations. The expected outcomes are corroborated (Table X); the results for both academic years are similar.

Table X. Tukey's HSD test

\begin{tabular}{l|lcccc}
\hline & (I) Students... & (J) Students ... & $\begin{array}{c}\text { Mean } \\
\text { Difference (I- } \\
\text { J) }\end{array}$ & $\begin{array}{c}\text { Standard } \\
\text { error }\end{array}$ & Sig. \\
\hline AY1 & Without project & With project & $-2.23683^{*}$ & 0.26213 & $\mathbf{0 . 0 0 0}$ \\
AY2 & Without project & With project & $-1.35413^{*}$ & 0.30334 & $\mathbf{0 . 0 0 0}$ \\
\hline
\end{tabular}


These findings demonstrate that the efforts of students involved in PrjBL are reflected in the exam score, which is higher than that of students who did not carry out any project.

The linear relationship between the project score and the exam score is analysed by using the sample of students who have undertaken a project for AY1 and AY2. The results of the OLS estimator appear in Table XI.

Table XI. Linear relationship between the project score and the course score

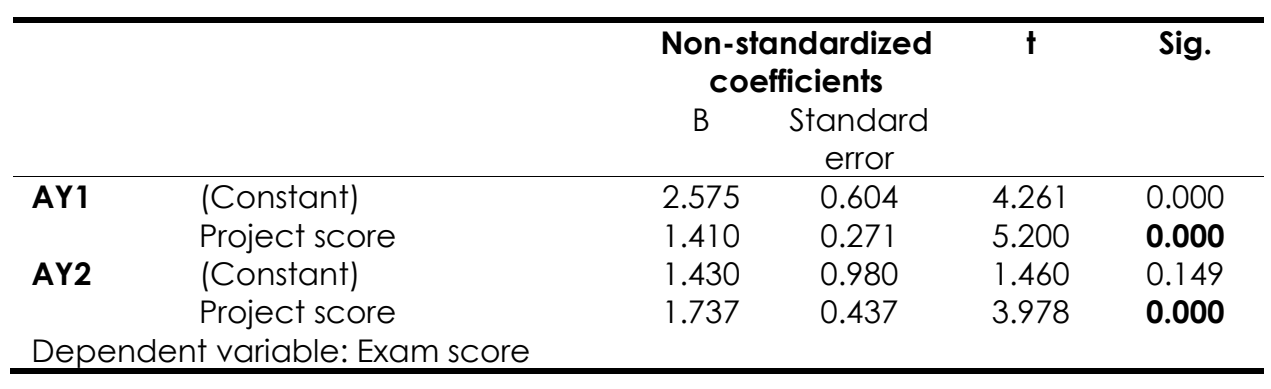

For $A Y 1$, an increase of 1 point in the project score results in an increase of 1.41 points in the exam score. There is a positive linear correlation of 0.561 , significant at $1 \%$ and an $\mathrm{R}^{2}$ of 0.314 , showing that the relationship is moderate-strong, such that there are other variables that may also explain the exam score.

The results for AY2 show that the estimated slope value has increased up to 1.737 and is significant at $1 \%$ with an $\mathrm{R}^{2}$ value of 0.193 . During this academic year, the explanation of the exam score by the project score has increased by 0.327 in relation to the previous academic year, although the relationship is weak.

Therefore, it can be expected that students involved in PrjBL in future academic courses would obtain higher scores than those who are not.

\section{DISCUSSION OF RESULTS AND CONCLUSIONS}

In response to the hypotheses established and the results obtained, it is clear that PriBL is perceived by most students as very useful in Advanced Accounting. The items that significantly explain the course score are related to the perception of its usefulness for learning, i.e., it helps verify the knowledge learnt in the classroom with its application to real situations, it bridges the gap between theory and practice, and it involves participants in their own learning. These findings corroborate the Bedford report (AAA, 1986) and authors such as Hwang et al. (2005) and Marriot and Marriot (2003) who note that accounting education must consider real situations, continuous changes in society and the environment, and the ability to adapt. Thus, $\mathrm{H} 1$ is accepted: students involved in PrjBL perceive the usefulness of this approach for learning.

The third hypothesis $(\mathrm{H} 3)$ proposes the relationship of the methodology to the development of skills desired in the profession. Among the most required skills, the following stand out: decision-making and problem-solving; skills that the White Paper (1989) identifies as essential to an accountant's professional profile; the AECC (1990) also notes problem-identification and problem-solving skills in a counselling process and in unfamiliar circumstances and the ability to implement problem-solving techniques in a consultation process. In accordance with these statements, authors such as Milner 
and Hill (2007), Hassall, Joyce, Arquero, and Donoso (2005), Arquero, Hassall, Donoso, and Joyce (2001), Boaler (1998), and Tretten and Zachariou (1997) agree that both are the most important abilities to develop for future graduates. The results show that students involved in PrjBL perceive that they develop instrumental, systemic, and interpersonal skills; student perceptions are high specifically with regard to decisionmaking and problem-solving. In line with Reyes (2005) and Boaler (1998), it can be stated that students learning through participatory methodologies develop their ability to make correct decisions.

Similarly, in line with the White Paper, another key ability that must be developed is the understanding of group dynamics or, as the AECC (1990) states, the ability to work in a team and influence its members and skills related to leadership, motivation, development, conflict-resolution, and the ability to interact with intellectually and culturally diverse people. The development of these skills produces a form of intellectual stimulation in the individual that leads to a high level of synergy in work groups (Peck, Gallucci, Sloan, \& Lippincott, 1998). The results show that students involved in this methodology perceive that they develop all of the items included in the set of interpersonal skills, but they most develop the ability to work in a team.

Another key skill for students' future career is oral and written communication (Arquero et al., 2001; Hassall et al., 2005; Milner \& Hill, 2007; Reyes, 2005; White Paper, 1989). According to the AECC (1990), communication is one of the skills that must be fostered in the education of future accounting professionals so that they may undertake creative presentations, enhance inductive and deductive reasoning, and conduct critical analysis. This skill is best perceived by students especially in AA, which confirms the assertion of Greenstein and Hall (1996): with this methodology, students are involved in the elaboration of cases, and oral and written communication skills are perceived as improving.

In short, the results show that PrjBL develops non-technical skills both in AA and AFA, stressing teamwork, interpersonal communication, and conflict management in AFA and oral and written communication in AA, essential skills for their future careers. Therefore, $\mathrm{H} 3$ is accepted: students involved in PrjBL perceive that they develop skills desired in the profession.

The above results confirm that students who are involved in PrjBL have a better level of performance than students who are not. In both AFA and AA, students participating in PrjBL perform better and there are significant differences in the scores of the students in the 'without project' group. Deepening the analysis of the academic achievement of the students in the 'with project' group, it may be demonstrated that there is a significant linear relationship between the score awarded to the project and the score on the exam.

There is an additional implication: the perception of usefulness for learning and developing skills desired in the profession differs according to the course. Although Bonner (1999),

Weil, Oyelere, and Rainsbury (2004) and Hwang et al. (2005) have argued that the use of active methodologies is effective in complex accounting subjects, it has been noted that the type of methodology to be applied differs depending on the knowledge that is 
intended to be transmitted (Knechel, 1992). Both courses in this study have very different profiles: AFA is a prescriptive subject that is highly concerned with accounting technique, whereas $A A$ is open-ended, interpretative, and creative. Because they have different syllabi, the use of PrjBL produces different perceptions. All the items for the perception of usefulness for learning are higher for AA (with a mean of 4.38) compared with AFA (with a mean of 3.80). With regard to skills development, it is clear that the methodology is most useful for AA because all 3 skills, i.e., instrumental (3.92 vs. 3.73), systemic (3.74 vs. 3.53), and interpersonal (3.89 vs. 3.66), a greater development for AA is perceived. Furthermore, the degree of satisfaction is higher in AA than in AFA: $84 \%$ of AA students would repeat the experience $(70 \%$ in AFA) and $70 \%$ of AA students believe that PriBL is optimal for learning (58\% in AFA), which is confirmed in the overall evaluation of the perception of the usefulness of the PrjBL approach (4.40 in AA versus 3.92 in AFA). Finally, the average exam score of students in the 'with project' group in AA is higher than the average exam score of students in AFA. Therefore, it is evident that the PrjBL approach is more effective in AA.

The limitations reducing the effectiveness of the PrjBL approach include uncontrollable external and internal factors. The fact that the subjects belong to a course of study that does not consider estimating the time spent for teamwork, in the form of credits, represents an effort-time overload for both the student and the teacher-tutor. Moreover, students involved in these methodologies sit for the traditional final exam at a pre-set date and time and are required to pass it to count on the project evaluation, which causes dissatisfaction because they consider their effort is not fully rewarded.

\section{REFERENCES}

ACCOUNTING EDUCATION CHANGE COMMISSION (AECC). (1990). Position statement $N^{0}$ 1. Objectives of education for accountants. Sarasota.

AMERICAN ACCOUNTING ASSOCIATION (AAA). (1986). Future accounting education: Preparing for the expanding profession (Informe Belford). Issues in Accounting Education, 1 (1), 168-195.

APOSTOLOU, B., DORMINEY, J. W., HASSELL, J. M., \& WATSON, S. F. (2013). Accounting education literature review (2010-2012). Journal of Accounting Education, 31 (2), 107-161. doi:10.1016/i.jaccedu.2013.03.001.

APOSTOLOU, B. A., HASSELL, J. M., REBELE, J. E., \& WATSON, S. F. (2010). Accounting education literature review (2006-2009). Journal of Accounting Education, 28(34), 145-197.

ApOStOlOU, B., WATSON, S. F., hasSell, J. M., \& WEBBER, S. A. (2001). Accounting education literature review (1997-1999). Journal of Accounting Education, 19, 1, $1-61$.

ARQUERO, J. L., HASSAL, T., DONOSO, J. A., \& JOYCE, J. (2001). Vocational skills in the accounting professional profile: The Chartered Institute of Management Accountants (CIMA) employers' opinion. Accounting Education: an International Journal, 10(3), 299-313. 
BARRon, B. J. S., SChWARtZ, D. L., Vye, N. J., MOORE, A., PETROSINO, A., ZECH, L., \& BRANSFORD, J. D. (1998). Doing with understanding: Lessons from research on problem- and project-based learning. Journal of the Learning Sciences, 7(3-4), $271-311$.

BENWARE, C. A., \& DECl, E. L. (1984). Quality of learning with an active versus passive motivational set. American Educational Research Journal, 21, 755-765.

BEREITER, C., \& SCARDAMALIA, M. (1999). Schools as knowledge-building communities. In D. Keating, \& C. Hertzman (Eds.), Developmental health and the wealth of nations. New York: The Guilford Press.

BLANK, W. (1997). Authentic instruction. In Promising practices for connecting high school to the real world. University of South Florida.

BLUMENFELD, P. C., SOlOWAY, E., MARX, R. W., KRAJCIK, J. S., GUZDIAL, M., \& PALINCSAR, A. (1991). Motivation project-based learning: Sustaining the doing, supporting the learning. Educational Psychologist, 26 (3-4), 369-398.

BOALER, J. (1998). Open and closed mathematics: Student's experiences and understandings. Journal for Research in Mathematics Education, 29, 41-62.

BONNER, S. E. (1999). Choosing teaching methods based on learning objectives: An integrative framework. Issues in Accounting Education, 14, 11-40.

CANDY, P., CREBERT, G., \& O'LEARY, J. (1994). Developing lifelong learners through undergraduate education. Canberra: Australian Government Publishing Service, National Board of Employment, Education and Training Report.

CARRASCO, A., DONOSO, J. A., DUARTE, T., HERNÁNDEZ, J., \& LÓPEZ, R. (2011). Análisis factorial confirmatorio del cuestionario que mide la efectividad del uso de metodologías de participación activa (CEMPA) [Confirmatory factor analysis of the questionnaire measuring the effectiveness of active participation techniques]. VIII Jornada de Docencia en Contabilidad [VIII Conference on Teaching Accounting], Palma de Mallorca.

CULLEN, J., RICHARDSON, S., \& O'BRIEN, R. (2004). Exploring the teaching potential of empirically-based case studies. Accounting Education, 13(2), 251-266.

DE MIGUEL DÍAZ, M. (2005). Cambio de paradigma metodológico en la educación superior. Exigencias que conlleva [Methodological paradigm shift in undergraduate education. Requirements involved]. Journal of European Integration, 2, 16-27.

DECl, E. L., \& RYAN, R. M. (1985). Intrinsic motivation and self-determination in human behavior. NEW YORK: PLENUM PRESS.

DICKINSON, K. P., SOUKAMNEUTH, S., YU, H. C., KIMBALL, M., D'AMICO, R., \& PERRY, R. (1998). Providing educational services in the Summer Youth Employment and Training Program. Washington, DC: U.S. Department of Labor, Office of Policy \& Research. 
DURTSCHI, C. (2003). The Tallahassee bean counters: A problem-based learning case in forensic auditing. Issues in Accounting Education, 18, 137-153.

ELAM, R. (1996). Accounting education research. Journal of Accounting Education, $14(2), 255-258$.

FRIEDLAN, J. M. (1995). The effects of different teaching approaches on students' perceptions of the skills needed for success in accounting courses and by practicing accountants. Issues in Accounting Education, spring, 47-64.

GALEANA DE LA O, L. (2006). Aprendizaje basado en proyectos [Project-based learning]. CEUPROMED. Retrieved from http://ceupromed.ucol.mx/revista/.

GODEJORD, P. A. (2007). Perspectives on project based teaching and "blended learning" to develop ethical awareness in students. Working paper. Retrieved from http://www.elearningeuropa.info/files/media/medial 4200.pdf.

GOODFREY, M. R. (1995). Case studies: Adventuring on teaching's high ground. National Teaching and Learning Forum, $4(6), 4-5$.

GREENSTEIN, M. M., \& HALL, J. A. (1996). Using student-generated cases to teach accounting information systems. Journal of Accounting Education, 14(4), 493514.

HAND, M. (2004a). The problem with faith schools: A reply to my critics. Theory and Research in Education, 2 (3), 343-353.

HAND, M. (2004b). On the desirability of education: A reply to John Wilson. British Journal of Educational Studies, 52(1), 18-27.

HARWELL, S. (1997). Project-based learning. In Promising practices for connecting high school to the real world. University of South Florida.

HASSALL, T., JOYCE, J., ARQUERO, J. L., \& DONOSO, J. A. (2005). Priorities for the development of vocational skills in management accountants: A European perspective. Accounting Forum, 29, 379-394.

HWANG, N. R., LUI, G., \& TONG, M. Y. J. W. (2005). An empirical test of cooperative learning in a passive learning environment. Issues in Accounting Education, 20, 151-166.

JONES, B. F., RASMUSSEN, C. M., \& MOFFITT, M. C. (1997). Real-life problem solving: A collaborative approach to interdisciplinary learning. Washington, DC: American Psychological Association.

KARLIN, M., \& VIANI, N. (2001). Project-based learning. Medford, OR: Jackson Education Service District. Working paper. Retrieved from http://www.jacksonesd.k12.or.us/it/ws/pbl/.

KNECHEL, W. R. (1992). Using the case method in accounting instruction. Issues in Accounting Education, 2, 205-217. 
LIBRO BLANCO PARA LA REFORMA DEL SISTEMA EDUCATIVO [White paper on the reform of the education system] (1989). Ministry of Education and Science, Government of Spain.

MARRIOT, P., \& MARRIOT, M. (2003). Are we turning them on? A longitudinal study of undergraduate accounting students' attitudes towards accounting as a profession. Accounting education. Anais: An International Journal, 12(2), 113133.

MARTINEZ, F., RUIZ, J. M., PEREZ, C., \& GONZALEZ, J. M. (2007). Definición de criterios de evaluación en metodología del aprendizaje basado en proyectos [Definition of evaluation criteria in the project-based learning approach]. Cuadernos de Innovación Educativa en las Enseñanzas Técnicas Universitarias [Notebooks on Educational Innovation in Academic and Technical Studies], 1, 2.

MAY, G. S., WINDAL, F. W., \& SYLVESTRE, J. (1995). The need for change in accounting education: An educator survey. Journal of Accounting Education, 13, 21-43.

MILNER, M. M., \& HILL, W. Y. (2007). Examining the skill debate in Scotland. Working paper. Retrieved from http://ssrn.com/abstract=1013530.

NORMAN, G. R., \& SCHMIDT, H. G. (1992). The psychological basis of problem-based learning: A review of the evidence. Academic Medicine, 67, 557-565.

PECK, C. A., GALLUCCI, C., SLOAN, T., \& LIPPINCOTT, A. (1998). Organizational learning and program renewal in teacher education: A socio-cultural theory of learning, innovation and change. Educational Research Review, 4(1), 16-25.

PENZO, W. (2009). Diseño y elaboración de actividades de aprendizaje [Learning activity design and development]. Working paper. Universidad de Barcelona. Retrieved from http://diposit.ub.edu/dspace/handle/2445/8448.

PIAGET, J. (1970). Piaget's theory. Monografías de Infancia y Aprendizaje [Children and Learning Monographs], 2, 1981.

Rebele, J. E., APOStOlOU, B. A., BuCKLesS, F. A., hassell, J. M., PAQuette, L. R., \& STOUT, R. D. (1988a). Accounting education literature review (1991-1997), Part I: Curriculum and instructional approaches. Journal of Accounting Education, $16(1), 1-51$.

Rebele, J. E., Apostolou, B. A., BuCKLess, F. A., hassell, J. M., PAQuette, L. R., \& STOUT, R. D. (1988b). Accounting education literature review (1991-1997), Part II: Students, educational technology, assessment and faculty issues. Journal of Accounting Education, 16(2), 179-245.

REBELE, J. E., STOUT, D. E., \& HASSELL, J. M. (1991). A review of empirical research in accounting education: 1985-1991. Journal of Accounting Education, 9(2), 167231.

REYES, E. (2005). Introducción al estudio de casos como método de enseñanza [Introduction to case studies as a teaching method]. Editorial Instituto de Ciencias de la Educación, Universidad de Zaragoza. 
REYNOLDS, J. (1990). El método del caso y la formación en gestión. Guía práctica [Case method and management training. Toolkit]. Valencia: Editorial IMPIVA.

RUGEN, L., \& HART, S. (1994). The lessons of learning expeditions. Educational Leadership, 52, 20-23.

SPRINGER, C. W., \& BORTHICK, A. F. (2004). Business simulation to stage critical thinking in introductory accounting: Rationale, design and implementation. Issues in Accounting Education, 19, 277-304.

THOMAS, J. W., MERGENDOLLER, J. R., \& MICHAELSON, A. (1999). Project-based learning: A handbook for middle and high school teachers. Novato, CA: The Buck Institute for Education.

TRETTEN, R., \& ZACHARIOU, P. (1997). Learning about project-based learning: Assessment of project-based learning in Tinkertech schools. San Rafael, CA: The Autodesk Foundation.

VYGOTSKY, L. (1978). Interaction between learning and development. In Mind and society (pp. 79-91). Cambridge; MA: Harvard University Press.

WASSERMANN, S. (1999). Estudio de casos como método de enseñanza [Case study as a teaching method]. Buenos Aires: Ed. Amorrortu.

WAtSON, S. F., APOStolou, B., HASSElL, J. M., \& WeBber, S. A. (2003). Accounting education literature review (2000-2002). Journal of Accounting Education, 21 (4), 267-325.

WATSON, S. F., APOStOlOU, B. A., HASSELL, J. M., \& WEBBER, S. A. (2007). Accounting education literature review (2003-2005). Journal of Accounting Education, 25(12), 1-58.

WEIL, S., OYElERE, P., \& RAINSBURY, E. (2004). The usefulness of case studies in developing core competencies in a professional accounting programme: A New Zealand study. Accounting Education, 13(2), 139-169.

ZABALZA, M. A. (2003). Competencias docents del profesorado universitario: Calidad y desarrollo profesional [The teaching skills of university teachers: Quality and professional development]. Madrid: Ed. Narcea. 
Appendix 1. Mean score analysis of students with and without projects in accounting courses from previous academic years.

The available data belong to a group of 123 students with a score greater than or equal to 5 in accounting courses prior to those under study in this paper. A total of 67 out of these 123 students are part of the 'without project' sample group, and 56 are part of the 'with project' sample group. The results allow us to conclude that there are no significant differences in the previous scores; thus, the ability of the students involved in both groups is controlled and is not an influencing factor in the results obtained.

Previous scores in accounting courses:

\begin{tabular}{|l|l|l|c|c|}
\hline & $\mathrm{N}$ & Mean & Standard deviation & Standard error of the mean \\
\hline Without project & 67 & 6.1972 & 1.27790 & 0.15974 \\
\hline With project & 56 & 6.3800 & 1.15043 & 0.15512 \\
\hline
\end{tabular}

The Levene's test leads us to assume the equality of variances in both groups. The t-statistic for the comparison of means does not reject the hypothesis of significant differences between the means of both groups.

\begin{tabular}{|l|l|l|l|l|}
\hline \multicolumn{2}{|l|}{ Levene's test for equality of variances } & \multicolumn{4}{|l|}{ T-test for equality of means } \\
\hline F & Sig. & $\dagger$ & gl & P-value \\
\hline 0.444 & 0.506 & -1.126 & 117 & 0.262 \\
\hline
\end{tabular}

